\title{
ВІЙСЬКОВО-ЦИВІЛЬНІ АДМІНІСТРАЦІї ЯК УНІКАЛЬНА ФОРМА ЦИВІЛЬНО-ВІЙСЬКОВИХ ВІДНОСИН В УМОВАХ НАДЗВИЧАЙНИХ ПРАВОВИХ РЕЖИМІВ
}

Дулгер В. В.

у статті цивільно-військові відносини розглядаються в діалектичному зв'язку з теорією національної безпеки і виключно з огляду на національні інтереси держави. Констатується, що сьогодні законодавство в галузі оборони країни ще не є єдиною цілісною системою, в ньому існують прогалини й суперечності. Визначається, що цивільно-військові відносини зазнають найбільш сильних змін за надзвичайних умов. Обґрунтовується, що національні інтереси $\epsilon$ ключовим елементом загальної системи національної безпеки і основним елементом системи впливу громадянського суспільства на військову організацію держави, і навпаки (що особливо рельєфно окреслено в надзвичайний період), оскільки вони забезпечують функціонування системи загальної безпеки країни. Стверджується, що діяльність військово-цивільних адміністрацій - це яскравий приклад не тільки впливу сектора безпеки і оборони на громадянське суспільство, але і запорука його збереження загалом. Проведений аналіз дав підстави для висновку про те, що найбільш очевидним вираженням зрілості громадянського суспільства є його ефективний контроль над сектором безпеки і оборони у звичайний час, а також здатність громадянського суспільства підпорядковуватися вимогам надзвичайних правових режимів в особливий період, що засвідчує його готовність адекватно сприйняти певні обмеження, коли цього вимагають національні інтереси.

Ключові слова: національна безпека, цивільно-військові відносини, військово-цивільні адміністрації, сектор безпеки та оборони, громадська безпека та порядок, надзвичайний правовий режим.

В статье гражданско-военные отношения рассматриваются в диалектической связи с теорией национальной безопасности и исключительно в контексте национальных интересов государства. Констатируется, что сегодня законодательство в области обороны страны еще не является единой челостной системой, в нем имеют место пробелы и противоречия. Определяется, что гражданско-военные отношения испытывают наиболее сильные изменения в чрезвычайных условиях. Обосновывается, что национальные интересы являются ключевым элементом общей системы национальной безопасности и основным элементом системы влияния гражданского общества на военную организацию государства, и наоборот (что особенно рельефно очерчено в чрезвычайный период), поскольку они обеспечивают функционирование системы общей безопасности страны. Утверждается, что деятельность военно-гражданских администраций - это яркий пример не только влияния сектора безопасности и обороны на гражданское общество, но и залог его сохранения как такового. Проведенный анализ дал основания для вывода о том, что наиболее очевидным выражением зрелости гражданского общества является его эффективный контроль над сектором безопасности и обороны в обычное время, а также способность гражданского общества подчиняться требованиям чрезвычайных правовых режимов в особый период, что свидетельствует о его готовности адекватно вос- принять определенные ограничения, когда этого требуют национальные интересы.

Ключевые слова: национальная безопасность, гражданско-военные отношения, военно-гражданские администрации, сектор безопасности и обороны, общественная безопасность и порядок, чрезвычайный правовой режим.

The article discusses civil-military relations in dialectical connection with the theory of national security. Today, the country's defense legislation is not yet a single, holistic system and there are gaps and contradictions. Civil-military relations vary greatly in emergency situations. National interests are a key element of the general system of national security and the main element in the system of influence of civil society on the military organization of the state, and vice versa (which is especially outlined in the emergency period), since they ensure the functioning of the country's general security system. The activities of civil-military administrations are a vivid example of not only the influence of the security and defense sectors on civil society, but also the key to its preservation. The most obvious expression of the maturity of a civil society is its effective control over the security and defense sector in normal times, but the ability of civil society to obey the requirements of emergency legal regimes in a particular period indicates its willingness to adequately accept certain restrictions when national interests require it.

The problem of civil-military relations has a long history. Even ancient thinkers paid much attention to the interaction of civilians and military men. The essential content of relations has changed, but their role as a factor in the sustainable development of society, its stability and security has never lost its significance.

It should be emphasized that the main criteria for the functioning of civil-military relations and the implementation of the state control system in the field of security and defense should be the national interests of Ukraine and the stable functioning of the military sphere, the entire system of national security of the state.

Undoubtedly, every element of government during a special period has a military component and directly influences the development and functioning of civil-military relations. In a thorough analysis of the relationship within the framework of civil-military relations, it is necessary to consider all the essential links and relations that affect the security and defense sector of the state and the functioning of the entire system of national security. Therefore, the purpose of further research is to analyze the methodological foundations of the activities of military-civilian administrations as a unique component of the national security system in a special period, as well as to study the specifics of their functioning in Ukraine.

Key words: national security, civil-military relations, civil-military administrations, security and defense sector, public security and order, emergency legal regime.

Гуйван П. Д., 2019 
Постановка проблеми та їі актуальність. Розроблення теорії цивільно-військових відносин для сучасного етапу розвитку України $\epsilon$ не тільки найважливішою науковою проблемою, але й має практичний характер. На жаль, до 2014 р. у вітчизняній науці, за невеликим винятком, проблеми відносин військової організації держави (або відповідно до ст. 4 Закону України «Про національну безпеку» [1] сектора безпеки і оборони) і суспільства в умовах особливих правових режимів не набули глибокого науково-теоретичного обґрунтування, тому військово-політична практика в контексті цивільно-військових відносин здійснювалася часом інтуїтивним шляхом, спиралась на теоретичні основи, розроблені переважно західними теоретиками соціально-політичної та правової думки, а також на концепції і моделі, які конституюються на пострадянському просторі.

Аналіз останніх досліджень і публікацій. Від початку збройної агресії проти нашої держави нагромаджено певний практичний досвід. 3'явилися і науково-теоретичні праці в цій галузі, серед яких слід виділити праці О.О. Гущина, І.М. Коропатніка, С.О. Кузніченка, В.В. Сокуренка, В.С. Шевченко, І.М. Шопіної та ін. [2]. Дані дослідження виступають теоретичною базою для розуміння діалектики взаємодії сектора безпеки і оборони та суспільства. Водночас нагальні проблеми, причинами появи яких стали події, що відбуваються на сході нашої держави, вимагають якнайскорішого вирішення.

В аналітичній доповіді Національного інституту стратегічних досліджень зазначено: «Система забезпечення національної безпеки України виявилася неспроможною ефективно протистояти російській агресії. Сектор безпеки та оборони як основний елемент системи забезпечення національної безпеки донині остаточно не сформований і не готовий діяти як єдина функціональна структура» [3, с. 7].

Мета статті - проаналізувати військово-цивільні адміністрації як одну з форм цивільно-військових відносин в умовах надзвичайних правових режимів.

Виклад основного матеріалу. На початку гібридної агресії РФ проти України у 2014 р. система гарантування національної безпеки через різні причини виявилася неготовою протистояти новим викликам і загрозам. Вище керівництво держави покинуло країну, органи сектора безпеки й оборони діяли не досить ефективно, катастрофічно бракувало ресурсів. Водночас на захист національних інтересів держави стало громадянське суспільство, взявши тимчасово на себе важливі функції у сфері забезпечення національної безпеки.

Такий процес взаємодії військової організації і суспільства в науковій літературі прийнято позначати терміном «військово-цивільні відносини» [4]. Він характеризує систему функціональних зв' язків, що вибудовуються між суспільством і військово-силовими структурами з приводу забезпечення воєнної безпеки.

Характер і зміст цивільно-військових відносин визначаються законом залежності військової організації держави від рівня суспільного розвитку. Цей загальносоціологічний закон конкретно проявляється в окремих закономірних процесах - у безпосередній залежності функціонування військово-цивільних відносин від рівня і стану матеріального виробництва, продуктивних сил і виробничих відносин, типу і ступеня зрілості політич- ної структури і політичних відносин, рівня і стану соціокультурного розвитку суспільства.

Основна функція цивільно-військових відносин полягає в тому, щоб об'єднати народ, збройні сили і політичне керівництво країни в процесі забезпечення іiі воєнної безпеки, а в разі потреби - у веденні воєнних дій, війни на захист Вітчизни.

Отже, суперечливість і динаміка розвитку соціально-політичної практики роблять життєво важливою необхідність концептуального розгляду і обґрунтування власної теорії цивільно-військових відносин у діалектичному зв'язку з теорією національної безпеки з огляду на національні інтереси держави.

Проблема цивільно-військових відносин має тривалу історію. Ще мислителі давнини приділяли багато уваги взаємодії цивільних і військових людей. Змінювався суттєвий зміст відносин, але їх роль як чинника сталого розвитку суспільства, його стабільності й безпеки ніколи не втрачала свого значення.

Цивільно-військові відносини $\epsilon$ складною системою взаємозв'язків і взаємовпливів громадянського суспільства і військової організації держави, виступають у формі соціального феномену, маючи характер цілісного явища і свою специфіку. Таким є підхід до розуміння даного феномену в широкому розумінні. У вузькому розумінні їх сторонами прийнято називати цивільних і військових як носіїв певного соціального представництва. Таке розуміння демонструють зарубіжні дослідники проблеми [4]. Категорії «цивільні» $\mathrm{i}$ «військові» вони доводять до абсолютного протиставлення, вважаючи, що вони відображають різні світи світ цивільних і світ військових, сфери цивільного і військового життя. Потрібно враховувати таку історичну тенденцію: військові виникають із цивільних і потім повертаються в їхню структуру. Взаємодія цивільних і військових засад суспільного життя має бути підпорядкована інтересам розвитку суспільства, держави та особистості, а також забезпеченню безпеки. Застосовуючи принцип системності до аналізу військової сфери, можна зробити висновок про те, що вона органічно вплетена в усі сфери суспільного життя.

Як переконливо показано в доповіді «Реформа демократичного цивільного контролю над Збройними силами та іншими військовими формуваннями в Україні: наступні кроки", підготовленій у 2018 р. співробітниками Інституту Євро-Атлантичного співробітництва [5], цивільно-військові відносини зазнають найбільш сильних змін, деформацій за надзвичайних умов. Їхнім головним джерелом розвитку $є$ постійний процес вирішення суперечностей у сферах військово-політичної дійсності, військово-політичної практики держави, реальних відносин у суспільстві і військовій організації, а рушійними силами - потреби, мотиви, інтереси і цілі безпечного розвитку державної системи, забезпечення територіальної цілісності країни. Крім того, можна виділити суперечність нормативно-правового характеру як одне з найбільш небезпечних явищ, оскільки використання військової сили поза межами концепції і законів держави виводить їі з правового поля, не забезпечує, а підриває військову безпеку держави [6].

Проблеми законодавчого забезпечення цивільно-військових відносин дуже різноманітні. Стан законодавства в секторі безпеки та оборони України характеризується тим, що за останні п'ять років було прийнято і всту- 
пило в силу багато основоположних нормативних актів, зокрема закони України «Про Раду національної безпеки і оборони України», «Про оборону України», «Про Збройні сили України», «Про мобілізаційну підготовку і мобілізацію», «Про організацію оборонного планування» тощо. У ряді випадків були запропоновані досить радикальні й глибокі реформи законодавства у сфері управління безпекою та обороною. Зокрема, відбулося ухвалення законів «Про Національну гвардію України», «Про Національну поліцію», «Про Державне бюро розслідувань». Уже декілька років очікується прийняття Закону України «Про військову поліцію». Дещо пізніше почали опрацьовуватися нові концептуальні документи в сфері національної безпеки та розроблятися програмні документи реформування структур безпеки. У 2015 р. були ухвалені необхідні концептуальні документи стратегічного рівня (Стратегія національної безпеки України та Воєнна доктрина України). Також були прийняті нові та вдосконалені наявні законодавчі акти у сфері регуляції загальнодержавних процесів координації та управління у секторі безпеки, у сфері здійснення адміністративного контролю на територіях, суміжних із зоною конфлікту, у сфері покращення управлінських механізмів під час особливого періоду (закони України «Про військово-цивільні адміністрації», «Про особливості державної політики із забезпечення державного суверенітету України на тимчасово окупованих територіях у Донецькій та Луганській областях»). Однак сьогодні законодавство в галузі обо-

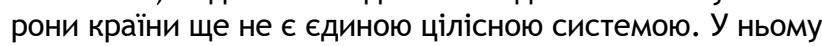
існують прогалини, суперечності, відсутні або $€$ в недостатній кількості норми прямої дії.

Як було сказано, проблеми організації відносин суспільства, армії і держави тільки починають комплексно опрацьовуватися в нашій правовій науці, а напрям цих досліджень сьогодні визначає практика. 3 огляду на це важливо на основі нагромадженого науково-теоретичного багажу та набутого практичного досвіду з урахуванням національних інтересів визначити власну модель цивільно-військових відносин.

Найбільш глибоке визначення предмета будь-якої теорії, як відомо, передбачає виявлення іiі законів і закономірностей [7]. Військово-цивільні відносини підпорядковані впливу цілого комплексу закономірностей, в яких виражаються зовнішні і внутрішні (генетичні, структурні і функціональні) зв'язки і взаємозалежності.

Закономірності військово-цивільних відносин $є$ стійкими, повторюваними й суттєвими зв'язками між суспільством і військовою організацією держави, реалізація яких дозволяє забезпечити надійну безпеку. Вони мають свою об'єктивну логіку незалежно від поглядів, програм політичних партій, окремих особистостей.

Цивільно-військові відносини - це діалектична єдність суспільства і військової організації держави, тобто цивільної і військової сфери, підпорядкована інтересам стабільного функціонування системи національної безпеки держави.

Дослідження впливу громадянського суспільства на військову організацію держави свідчить про те, що він здійснюється комплексно і становить певну систему, основними структурними компонентами якої $\epsilon$ національні інтереси, цінності громадянської культури, нормативно-правові акти та процедури, масові громадські організації громадян і самих військовослужбовців, засоби масової інформації [8].
Не викликає заперечень думка про те, що саме національні інтереси $\epsilon$ ключовим елементом загальної системи національної безпеки і основним елементом системи впливу громадянського суспільства на військову організацію держави, і навпаки (що особливо рельєфно окреслено в надзвичайний період), оскільки вони забезпечують функціонування системи загальної безпеки країни.

У 2018 р. був прийнятий Закон України «Про національну безпеку України» [1], який створив правову базу для формування нової якості системи забезпечення національної безпеки відповідно до сучасних вимог. До його розроблення були залучені найкращі вітчизняні експерти, представники держави та громадськості. Важливо, що в роботі над цим законопроєктом були враховані принципи та стандарти НАТО і $Є С$, які існують у сфері забезпечення національної безпеки.

Такий Закон $є$ рамковим, тому він визначає правові основи визначеної сфери суспільних відносин із відповідною деталізацією та конкретизацією його положень в інших законах і підзаконних нормативно-правових актах. Принципово важливим $€$ визначення в Законі порядку організації взаємодії державних органів, громадських організацій, посадових осіб та окремих громадян, об'єднаних цілями та завданнями захисту національних цінностей та інтересів.

У нашому дослідженні під національними інтересами України розуміємо складне і багатоаспектне явище, що являє собою усвідомлені, об'єктивно існуючі, що випливають з самого факту існування в світі націй і держав, різноманітні потреби, які несуть на собі відбиток національних духовних цінностей і конкретизуються на державному рівні у вигляді офіційно проголошених цілей і політико-правових установок.

Слід зауважити, що важливою складовою частиною забезпечення національної безпеки $є$ підтримання громадської безпеки і порядку, тобто захищеності життєво важливих для суспільства та особи інтересів, прав і свобод людини і громадянина, забезпечення яких $\epsilon$ пріоритетним завданням діяльності сил безпеки, інших державних органів, органів місцевого самоврядування, їх посадових осіб та громадськості, які вживають узгоджених заходів щодо реалізації і захисту національних інтересів від впливу загроз [1].

Збалансовані інтереси особистості, суспільства, держави визначають національні інтереси України в політичній, економічній, науково-технологічній, соціальній, демографічній, інформаційній, військовій, екологічній сферах, відображаючи одночасно внутрішні і міжнародні відносини.

Отже, національні інтереси України $\epsilon$ стрижневим елементом загальної системи безпеки i, на нашу думку, основним елементом системи впливу громадянського суспільства на сектор безпеки і оборони. Специфіка такого впливу детермінується ступенем зрілості, сформованістю самого громадянського суспільства і сучасним етапом суспільного розвитку нашої держави. Не випадково серед основних напрямів нейтралізації внутрішніх джерел загроз $\epsilon$ визначення стратегії громадської безпеки, без якої неможливе формування в Україні громадянського суспільства, що $€$ одним із важливих чинників забезпечення воєнної безпеки.

Одним з елементів системи забезпечення воєнної безпеки $\epsilon$ готовність захищати національні інтереси 
особистості, суспільства і держави. Сьогодні Україна перебуває на вирішальному етапі вдосконалення громадянського суспільства і відповідного йому сектора безпеки і оборони.

Важливим елементом стійкості держави $є$ забезпечення безперервності процесу управління навіть за умов настання кризової ситуації. Крім створення системи запобіжних механізмів у вигляді чітких схем розподілу обов'язків і заміщення посад у сфері державного управління, великого значення набуває також питання децентралізації влади як інструменту формування національної стійкості, зокрема й у сфері національної безпеки.

Такий підхід робить систему гарантування національної безпеки більш гнучкою, здатною забезпечити оперативне реагування на загрози на територіальному рівні. При цьому відбувається доцільний перерозподіл повноважень у безпековій сфері між центральною і місцевою владою (за умови збереження ключової ролі держави та посилення ії контрольної й координаційної функцій), створення (посилення) місцевих сил безпеки й оборони (зокрема, загонів територіальної оборони, цивільного захисту, охорони громадського порядку, відповідних об'єднань громадян тощо). Крім того, надмірна концентрація владних повноважень в одному центрі підвищує ризик припинення надання суспільству критично важливих функцій в умовах колапсу державного управління. Загалом такий підхід дає змогу більш ефективно протистояти широкому спектру загроз, зокрема гібридних, спрямованих на державну безпеку, поглинати їх уже на локальному рівні.

Яскравим прикладом такого управління $\epsilon$ військово-цивільні адміністрації, організацію, повноваження і порядок діяльності яких визначено відповідним законом [9]. Військово-цивільні адміністрації вимушено створюються як тимчасові органи з елементами військової організації управління для забезпечення безпеки та нормалізації життєдіяльності населення в районі проведення збройної відсічі агресії, що не має на меті зміну та (або) скасування конституційно закріпленого права територіальних громад на місцеве самоврядування.

Тобто таке управління здійснюється в унікальній формі цивільно-військового співробітництва - у формі взаємодії цивільної та військової адміністрацій, спрямованої на забезпечення першочергового виконання сектором безпеки і оборони завдань щодо захисту суверенітету та недоторканності державної території, забезпечення громадського порядку і безпеки, а також суспільно-політичних та соціально-економічних процесів розвитку територій з урахуванням особливостей проведення відсічі збройній агресії. Тут військово-цивільне співробітництво реалізується шляхом координації зусиль сектора безпеки і оборони та цивільних адміністрацій.

На нашу думку, можна стверджувати, що діяльність військово-цивільних адміністрацій - це яскравий приклад не тільки впливу сектора безпеки і оборони на громадянське суспільство, але й запорука його збереження як такого. Головне завдання підрозділів (частин) військово-цивільного адміністрування - це організація співпраці із цивільним населенням, місцевими органами влади, іншими військовими формуваннями, що перебувають на постійній чи тимчасовій основі в певній зоні, урядовими та неурядовими організаціями, релігійними громадами в районі конфлікту або катастрофи. Фахівці підрозділів військово-цивільного адміністрування виконують роль єднальної ланки між формуваннями регулярних збройних сил (правоохоронних силових структур) і мирними мешканцями зони конфлікту та відповідають за інформаційний складник забезпечення співробітництва. Професіонали координують діяльність військових, правоохоронних, урядових, неурядових, міжнародних, благодійних, релігійних та інших організацій стосовно безпосереднього надання допомоги та забезпечення постраждалих верств населення, забезпечення громадського порядку та безпеки.

Висновки. Підсумовуючи, слід наголосити, що найбільш очевидним вираженням зрілості громадянського суспільства з огляду на проведений аналіз $\epsilon$ його ефективний контроль над військовою організацією держави (сектором безпеки і оборони) і системою національної безпеки країни в мирний час. Водночас здатність громадянського суспільства підпорядковуватися вимогам надзвичайних правових режимів в особливий період засвідчує його готовність адекватно сприймати певні обмеження, якщо цього вимагають національні інтереси.

Необхідно підкреслити, що основними критеріями функціонування цивільно-військових відносин і реалізації системи державного контролю в галузі безпеки і оборони повинні бути національні інтереси України і стабільне функціонування військової сфери, усієї системи національної безпеки держави.

Безумовно, кожен елемент управління в особливий період має військові складники і безпосередньо впливає на розвиток і функціонування цивільно-військових відносин. При детальному аналізі взаємозв'язків у рамках цивільно-військових відносин необхідно розглядати всі істотні зв'язки і відносини, що впливають на сектор безпеки і оборони держави та функціонування всієї системи забезпечення національної безпеки. Отже, метою подальшого дослідження стане аналіз методологічних основ діяльності військово-цивільних адміністрацій як унікальних складників системи забезпечення національної безпеки в особливий період, а також вивчення специфіки їх функціонування в Україні.

\section{Література}

1. Про національну безпеку України : Закон України від 21 червня 2018 року № 2469-VIII. Відомості Верховної Paдu. 2018. № 31. Ст. 241.

2. Кузніченко С.О., Шевченко В.Й. Військово-цивільні адміністрації в Україні: досвід комплексного дослідження : монографія ; Ін-т законодавства Верховної Ради України. Одеса, 2017. 182 с.; Коропатнік І.М. Взаємодія громадянського суспільства і Збройних сил України: адміністративно-правові засади : монографія. Київ : Леся, 2016. 412 с.; Сектор безпеки і оборони України: стратегічне керівництво та військове управління : монографія / Саганюк Ф.В., Фролов В.С., Павленко В.І. та ін. ; за ред. д. військ. Н., проф. І.С. Руснака. Київ : ЦЗ МО та ГШ ЗС України, 2018. 230 с.; Сокуренко В.В. Публічне адміністрування сфери оборони в Україні : автореф. дис. ... д-ра юрид. наук : 12.00 .07 ; Нац. юрид. ун-т ім. Ярослава Мудрого. Харків, 2016. 40 с.; Шопіна І.М., Гущин 0.О. Актуальні проблеми сучасного стану розвитку воєнного (військового) права як науки і навчальної дисципліни. Форум права. 2017. № 2. С. 144-148; Шульгін В.В. Реалізація військового законодавства України: історія, теорія, практика, шляхи удосконалення : монографія. Київ : РВЦ «Військовий інститут», 2018. 186 C.

3. Про внутрішнє та зовнішнє становище України у сфері національної безпеки : Аналітична доповідь Національ- 
ного інституту стратегічних досліджень до позачергового Послання Президента України до Верховної Ради України. Київ : НІСД, 2014. 148 с.

4. Скворцов В. Цивільно-військові відносини і тенденції світового політичного процесу. Політичний менеджмент. 2008. № 6. С. 97-104.

5. Козій І., Поляков Л. Реформа демократичного цивільного контролю над Збройними силами та іншими військовими формуваннями в Україні: наступні кроки. Київ : Інститут Євро-Атлантичного співробітництва, 2018. 39 c.

6. Шамрай В.О. Державне управління військовими формуваннями воєнної організації: стан та тенденції розвитку в сучасній Україні : автореф. дис. ... д-ра наук
3 держ. упр. : 25.00 .03 «Орг. і упр. в держ. установах». Київ, 1999. 38 с.

7. Петрушенко В.Л. Філософія : навч. посібник. Львів : Новий світ 2000, 2012. 647 с.

8. Цивільно-військове співробітництво за стандартами НАТО : навч. посіб. Київ : Національний університет оборони України імені Івана Черняховського, 2015. 87 с.

9. Про військово-цивільні адміністрації Закон України від 3 лютого 2015 р. № 141-VIII. URL: http://zakon3.rada.gov.ua/laws/show/141-19.

Дулгер В. В., здобувач

Одеського державного університету внутрішніх справ 